\title{
First endocranial description of a South American hadrosaurid: The neuroanatomy of Secernosaurus koerneri from the Late Cretaceous of Argentina
}

Marcos G. Becerra, Ariana Paulina-Carabajal, Penélope Cruzado-Caballero, and Jeremías R.A. Taborda Acta Palaeontologica Polonica 63 (4), 2018: 693-702 doi:https://doi.org/10.4202/app.00526.2018

The endocranial morphology of Secernosaurus koerneri (= Kritosaurus australis junior synonym), a hadrosaurid from

the Upper Cretaceous of Argentina, was studied using latex and digital endocasts based on three fragmentary braincases. This new information allowed describing and comparing the neuroanatomy of this South American representative of the clade for the first time. The endocast morphology is mostly complete (except for the pituitary and the inner ear regions), and most cranial nerves and some blood vessels were reconstructed. Also, some features of the inner ear were observed in the CT scans, nonetheless its incompleteness restricts further comparisons. Secernosaurus koerneri shares its overall endocranial morphology with saurolophinid hadrosaurids, indicating a conservative brain morphology for Cretaceous hadrosaurids worldwide. The novel cranial information increases the knowledge of the neuroanatomy in hadrosaurids by adding a southern perspective, since knowledge on the endocranial anatomy of the lineage is biased by species from North America.

Key words: Dinosauria, Hadrosauridae, Secernosaurus koerneri, endocast, neuroanatomy, Cretaceous, South America, Argentina.

Marcos G. Becerra [mbecerra@mef.org.ar], Consejo Nacional de Investigaciones Científicas y Técnicas (CONICET), Museo Paleontológico Egidio Feruglio (MEF), Fontana 140, Trelew U9100GYO, Chubut, Argentina. Ariana Paulina-Carabajal [a.paulinacarabajal@conicet.gov.ar ], Instituto de Investigaciones en Biodiversidad y Medioambiente (CONICET-UNCo), Quintral 1350, San Carlos de Bariloche 8400, Río Negro, Argentina. Penélope Cruzado-Caballero [pccaballero@unrn.edu.ar], Instituto de Investigación en Paleobiología y Geología, Universidad Nacional de Rio Negro (CONICET-UNRN), Av. General Roca 1242, General Roca 8332, Río Negro, Argentina. Jeremías R.A. Taborda [jeremias.taborda@ conicet.gov.ar], Centro de Investigaciones en Ciencias de la Tierra (CICTERRA), Consejo Nacional de Investigaciones Científicas y Técnicas (CONICET), Universidad Nacional de Córdoba, FCEFyN, Vélez Sarsfield 1611, 
Ciudad Universitaria X5016GCA, Córdoba, Argentina.

This is an open-access article distributed under the terms of the Creative Commons Attribution License (for details please see creativecommons.org), which permits unrestricted use, distribution, and reproduction in any medium, provided the original author and source are credited.

FoFif Full text $(817.9 \mathrm{kB})$ ।

FoF Supplementary file $(70.7 \mathrm{kB})$ 